DOI: 10.12731/2658-6649-2019-11-5-17-20

УДК 616.72 - 002.772

\title{
РАЗВЕРНУТЫЙ АНАЛИЗ КРОВИ ПРИ ЮВЕНИЛЬНОМ ИДИОПАТИЧЕСКОМ АРТРИТЕ У ДЕТЕЙ, ПРОЖИВАЮЩИХ В КРАСНОЯРСКОМ КРАЕ
}

Акопова Ю.С., Миллер О.М., Акопова И.С.

Целью исследования являлось изучение клинического анализа крови при ювенильном идиопатическом артрите. Было показано, что в крови у детей с ювенильным идиопатическом артритом увеличивается число лимфочитов и моноцитов, тромбоцитов, нейтрофилов, повымается скорость оседания эритроиитов. Достоверно уменьшается содержание гемоглобина и средний объем эритрочита.

Ключевые слова: ювенильный идиопатический артрит; лимфочиты; моночитығ; тромбоцить;; нейтрофиль;; скорость оседания эритроцитов.

\section{CLINICAL BLOOD IN PATIENTS WITH JUVENILE IDIOPATHIC ARTHRITIS IN KRASNOYARSK REGION}

\author{
Akopova J.S., Miller O.M., Akopova I.S.
}

The aim of the study - assessment of the features of clinical blood in patients with juvenile idiopathic arthritis. It showed an increase in the absolute number of lymphocytes and monocytes, platelets, neutrophils, increased erythrocyte sedimentation rate in children with juvenile idiopathic arthritis. Significantly decreased hemoglobin and mean corpuscular volume.

Keywords: juvenile idiopathic arthritis; lymphocytes; monocytes; platelets; neutrophils; erythrocyte sedimentation rate.

\section{Введение}

Системному ювенильному идиопатическому артриту (ЮИА) подвержены дети в возрасте до 16 лет $[1,2]$. Ревматическое заболевание системного характера может сопровождаться на фоне суставного синдрома лихорадкой, генерализованной лимфоаденопатией, гепатомегалией и/или спленомегалией [3]. Целью данного исследования было проследить из- 
менения в клиническом анализе крови у детей, страдающих ювенильным идиопатическим артритом.

\section{Материалы и методы исследования}

Обследовано 50 детей 4-12 лет. На базе Красноярского Краевого клинического центра охраны материнства и детства с 8.30 часов до 9.30 часов забиралась венозная кровь (25 детей с ЮИА). Группа контроля набиралась на базе Городской детской больницы № 4 (25 детей группы контроля). Определение развернутого анализа крови проводили на автоматическом гематологическом анализаторе Advia 2120i фирмы Siemens. Статистический анализ результатов исследования проводили с помощью пакетов прикладных программ SPSS 8,0 и «Statistica7,0». Проверку гипотезы о статистической достоверности двух выборок проводили непараметрическим методом с помощью критерия Манна-Уитни.

\section{Результаты исследования}

В результате исследования были получены статистически значимые изменения. У детей с ЮИА в крови присутствуют повышенные значения СОЭ: 30,00 мм/ч $(21,13 ; 40,04)$, свидетельствующие о воспалении, по сравнению со здоровыми детьми - 5,22 мм/ч $(4,15 ; 6,90)(\mathrm{P}=0,006)$. При ЮИА по значению СОЭ можно оценить степень активности воспалительного процесса. Число лейкоцитов у больных детей значительно выше $-17,08 * 10^{9} /$ л $(11,30 ; 20,32)$, а в группе контроля $-7,80^{*} 10^{9} / л(6,10 ; 8,80)(\mathrm{P}=0,009)$, при норме по возрасту - от 4,5 до $10^{*} 10^{9} /$ л, при этом сдвиг лейкоформулы у больных детей наблюдается влево [3]. Среди незрелых гранулоцитов встречаются метамиелоциты, миелоциты, палочкоядерные нейтрофилы. У детей с ЮИА число лимфоцитов $(40,90 \%(35,80 ; 46,10))(\mathrm{P}=0,0006)$ и моноцитов $7,25 \%(5,25 ; 9,30)$ достоверно выше, чем у здоровых лимфоцитов $-25,00 \%$ $(22,00 ; 32,00)(\mathrm{P}=0,006)$ и моноцитов $-5,00 \%(4,00 ; 6,00)(\mathrm{P}=0,008)$, но показатели укладываются в пределы нормальных значений (моноциты: от 2 до 10, лимфоциты: от 24 до 60). О тромбоцитозе свидетельствует повышенное число тромбоцитов: $319,00109 /$ л $(242,00 ; 392,00)$ по сравнению с группой контроля - 267,0 109/л $(237,00 ; 292,00)(\mathrm{P}=0,04)$. Тромбоцитоз у больных ЮИА является неспецифической реакцией на воспалительный процесс и связан с клинико-лабораторными показателями активности заболевания.

\section{Обсуждение}

Отмечено, что умеренная тяжесть анемии у детей с ЮИА. Уровень гемоглобина у детей с ЮИА 100,00 г/л $(94,31 ; 125,00)$, а у здоровых - 129,00 
г/л $(122,00 ; 131,00)(\mathrm{P}=0,023)$. Анемия сопровождается гипоксией тканей и может приводить к повреждению различных органов и систем. На наличие анемии у детей с ЮИА указывает также достоверное снижение гематокрита ниже нормы. Также обнаружено снижение эритроцитарного индекса - среднего объема эритроцита (выражен в фемтолитрах, в норме от 80 фл до 100 фл). Эритроциты со средним объемом ниже нормы (у детей с ЮИА 78,05 фл $(75,80 ; 79,65))$ встречаются при анемии, не связанной с дефицитом в организме витамина В12, либо фолиевой кислоты [3]. У здоровых детей гемоглобин составил 129,00 фл $(122,00 ; 131,00)(\mathrm{P}=0,003)$. Предполагают, что у детей с ЮИА железо из распадающихся эритроцитов остается в виде запасов в органах ретикулоэндотелиальной системы. Так у детей с ЮИА наблюдается гипохромная анемия $[1,2,3]$.

\section{Заключение}

Исследование показало, что наблюдаемые изменения в развернутом анализе крови у детей с ЮРА носят неспецифический характер, однако лабораторные исследования необходимы для обнаружения воспаления, контроля активности заболевания и эффективности лечения.

\section{Список литературы}

1. Жолобова Е.С. Системная форма ювенильного идиопатического артрита (диагностика и лечение) /Е.С. Жолобова //Русский медицинский журнал. 2012. № 30. C. 1514.

2. Sikora K.A. Update on the pathogenesis and treatment of systemic idiopathic arthritis / K.A. Sikora, A.A. Grom //Current opinion pediatrics. 2011. № 23(6), pp. 1-2.

3. Дмитриева Л.Т. Влияние физиотерапии на клинические и иммунологические параметры у детей с ювенильным ревматоидным артритом /Л.Т. Дмитриева, Т.Л. Настаушева //Саратовский научно-медицинский журнал. 2008. T.4, № 22. C. 67.

\section{References}

1. Zholobova E.S. Sistemnaja forma juvenil'nogo idiopaticheskogo artrita (diagnostika i lechenie) [Systemic form of juvenile idiopathic arthritis (diagnosis and treatment)]. Russkij medicinskij zhurnal, 2012, № 30, pp. 1514.

2. Sikora K.A., Grom A.A. Update on the pathogenesis and treatment of systemic idiopathic arthritis [Update on the pathogenesis and treatment of systemic idiopathic arthritis]. Surrent opinion pediatrics, 2011, № 23(6), pp. 1-2.

3. Dmitrieva L.T., Nastausheva T.L. Vlijanie fizioterapii na klinicheskie i immunologicheskie parametry u detej s juvenil'nym revmatoidnym artritom [The impact of 
physiotherapy on clinical and immunological parameters in children with juvenile rheumatoid arthritis]. Saratovskij nauchno-medicinskij zhurnal, 2008, V.4, № 22. P. 67.

\section{ДАННЫЕ ОБ АВТОРАХ}

Акопова Юлия Семёновна, доцент, канд. биол. наук

Сибирский Федеральный Университет

пр. Свободный, 79, г. Красноярск, 660041, Российская Федераџия yakopova@sfu-kras.ru

Миллер Ольга Михайловна, биолог клинико-диагностической лаборатории Красноярский краевой клинический центр охраны материнства и детства

ул. Академика Киренского, 2a, Красноярск, 660074, Российская Федерачиия

0406197811@rambler.ru

Акопова Ирэна Семеновна, врач-бактериолог, канд. биол. наук Филиал Федерального бюджетного учреждения здравоохранения «Центр гигиены и эпидемиологии в Красноярском крае»

ул. Мира, 5, г. Лесосибирск, Красноярский край, 662547, Российская Федерация

akopovairena@mail.ru

\section{DATA ABOUT THE AUTHORS}

Akopova Julia Semenovna, Associate Professor, Candidate of Biological Sciences Siberian Federal University

79, Svobodny pr., Krasnoyarsk, 660041, Russian Federation yakopova@sfu-kras.ru

Miller Olga Mikhailovna, Biologist of Clinical-Diagnostic Laboratory Krasnoyarsk Regional Clinical Center of Maternal and Child Health 2a, Akademica Kirenskogo str., Krasnoyarsk, 660074, Russian Federation 0406197811@rambler.ru

Akopova Irena Semenovna, Physician-Bacteriologist, Candidate of Biological Sciences

Center of Hygiene and Epidemiology in the Krasnoyarsk

5, Mira str., Lesosibirsk, Krasnoyarsk region, 662547, Russian Federation akopovairena@mail.ru 